\title{
PERLINDUNGAN HUKUM TERHADAP ANAK SEBAGAI PERANTARA NARKOTIKA (Studi Putusan No.14/Pid.Sus Anak.2015/PN.Dps)
}

\author{
Rezky Ayu Saraswati, I Nyoman Sujana, Diah Gayatri Sudibya \\ Fakultas Hukum Universitas Warmadewa, Denpasar-Bali, Indonesia
}

\begin{abstract}
Abstrak
Masalah peredaran narkotika yang dilakukan oleh anak sebagai perantara narkotika perlu mendapat perhatian seluruh komponen bangsa dan masyarakat. Anak sebagai pelaku tindak pidana harus tetap mendapatkan perlindungan demi kepentingan anak itu sendiri. Perlindungan anak terdapat dalam Undang-undang Nomor 11 tahun 2012 tentang sistem peradilan pidana anak, dimana pada saat ini anakpun dapat sebagai penyalahgunaan narkotika bahkan sebagai perantara narkotika. Dengan maraknya penyalahgunaan narkotika bagi seluruh kalangan baik di Indonesia maupun di dunia Internasional. Penelitian ini bertujuan untuk mengetahui dasar pertimbangan hakim dalam menjatuhkan sanksi pidana terhadap anak sebagai perantara narkotika, dan untuk mengetahui perlindungan hukum terhadap anak sebagai perantara narkotika. Permasalahan yang akan dibahas nantinya akan dikaji berdasarkan sudut pandang hukum normatif dan pendekatan perundang-undangan dengan putusan pengadilan negeri denpasar No.14/Pid.Sus Anak/2015/PN.Dps. Hasil penelitian menunjukkan bahwa hakim menimbang bahwa terdakwa anak telah melakukan tindak pidana narkotika dengan dijerat dengan perundangan tentang narkotika, dimana dapat dijatuhkan hukuman pidana. Kemudian, perlindungan hukum terhadap anak dilakukan oleh hakim dengan cara menjatuhkan pidana pelatihan kerja di yayasan generasi bisa Indonesia agar anak tetap dapat menjalankan aktifitasnya seperti biasa saat kembali kemasyarakat dan tidak mengganggu psikisnya dan mendapatkan haknya sebagai anak dan dapat menambah ilmu ketrampilan terhadap anak agar anak tidak kembali melakukan tindak pidana.
\end{abstract}

Kata kunci: Anak sebagai Kurir Narkotika; Perlindungan Hukum; Sanksi Pidana; Tindak Pidana Narkotika.

\begin{abstract}
The problem of narcotics circulation carried out by children as narcotics intermediaries needs the attention of all components of the nation and society. Children as perpetrators of criminal acts must still receive protection for the sake of the child's own interests. Child protection is contained in Law Number 11 of 2012 concerning the juvenile criminal justice system, where at this time even children can act as narcotics abuse and even as narcotics intermediaries. With the rampant abuse of narcotics for all groups both in Indonesia and in the international world. This study aims to determine the basis for judges' considerations in imposing criminal sanctions on children as narcotics intermediaries, and to determine the legal protection of children as narcotics intermediaries. The issues to be discussed will later be studied based on a normative legal point of view and a statutory approach with the decision of the Denpasar District Court No.14 / Pid.Sus Anak / 2015 / PN.Dps. The results showed that the judge considered that the child accused had committed a criminal offense of narcotics by being charged with the law on narcotics, in which a criminal sentence could be imposed. Then, legal protection for children is carried out by judges by imposing work training penalties at the Indonesian generation foundation so that children can continue to carry out their activities as usual when they return to society and do not interfere with their psychology and get their rights as children and can add knowledge of skills to children so that children do not. return to committing a crime.
\end{abstract}

Keywords: Children as Narcotics Courier; Legal protection; Criminal sanctions; Narcotics Crime.

\section{PENDAHULUAN}

Upaya perlindungan hukum untuk anak-anak telah dibahas cukup lama baik di Indonesia maupun di dunia internasional (Prajnaparamita, 2018). Diskusi mengenai hal ini tidak akan berhenti, karena selain menjadi masalah universal, juga karena di dunia ini selalu dihiasi anak-anak. Selama dunia tidak sepi oleh anak-anak selama itu yang akan dibahas masalah anak. Anak-anak memiliki peran penting dalam kehidupan masyarakat dan negara, karena mereka bangsawan, yang fondasinya telah diletakkan pada generasi sebelumnya, dalam rangka mewujudkan tujuan membentuk pemerintahan 
yang melindungi rakyatnya. Sebagai pelaksana cita-cita bangsa, anak-anak memiliki kewajiban mulia dan tanggung jawab berat untuk mewujudkan tujuan Republik Indonesia.

Penyalahgunaan narkotika yang dilakukan anak-anak mendapat perhatian yang cukup dari semua kalangan dan berbagai kelompok. Semua kalangan saling mengingatkan rakyat Indonesia. Permasalahan penyalahgunaan narkotika merupakan kejahatan narkotika. Perundangan tidak membedakan secara khusus antara pelaku kejahatan narkotika. Baik yang memerintahkan maupun yang melakukan dan ikut berpartisipasi dalam melakukan tindak pidana tersebut (Sujono \& Daniel, 2011). Seorang anak adalah merupakan bagian dari generasi penerus dan menjadi harta sebagai penerus cita-cita perjuangan bangsa. Anak mempunyai peran strategis dan memiliki ciri serta sifat khusus yang menjamin keberlangsungan bangsa dan negara di masa yang akan datang. Anak adalah harapan orang tua, harapan nusa dan bangsa. Sehingga perlu dilakukan pembinaan yang bersifat berkelanjutan untuk kelangsungan hidup, perkembangan mental dan sosial serta melindungi anak dari pengaruh yang berbahaya dan bisa merusak masa depan anak tersebut.

Perlindungan hukum ialah mengayomi hak asasi manusia yang dirugikan dan perlindungan diberikan kepada rakyat supaya bisa menjalani semua hak yang diberikan oleh hukum atau langkah hukum yang diberikan oleh penegak hukum agar masyarakat dapat menikmati rasa aman dan jauh dari kejahatan dan ancaman yang datang dari manapun juga (Hidayat, 2010). Anak yang menjalani kasus pidana sangat pelru diberikan perlindungan hukum, karena mereka mempunyai hak dan kewajiban. Kewajiban anak adalah menaati peraturan yang berlaku sehingga dapat menyelesaikan kasus yang dihadapi dengan tertib dan dan mendapat hak sesuai umur dan mereka tetap mendapatkan sanksi sesuai dengan umur anak tersebut. Anak-anak yang terlibat kejahatan narkotika adalah serangkaian konspirasi dalam melakukan perdagangan obat terlarang, namun dalam kategori anak sebagai perantara, ini adalah satu hal yang sangat mengkhawatirkan di mana anak tersebut dihadapkan pada hukum dan diklasifikasikan sebagai penjahat narkotika yang bertindak. Posisinya sebagai calon penerus bangsa. Sehingga anak berpotensi aktif dalam menjaga kelestarian dan kehidupan nasional yang strategis, dari berbagai aspek dan turut serta dalam memerangi kejahatan narkotika (Gultom, 2014).

Menurut perundangan-undangan narkotika bahwa Narkotika merupakan zat/obat yang bahannya dari tumbuh-tumbuhan atapun non tumbuhan, baik semisintetik maupun sintetis sehingga turunnya atau terjadi perubahan terhadap kesadaran, kehilangan rasa sakit dan bisa menimbulkan ketergantungan. Perundangan tentang narkotika sudah mengatur mengenai hukuman terhadap siapa pun yang dikenai dan mengatur denda yang perlu di bayar. Penggunaan hukum pidana terhadap anak-anak sebagai cara mengatasi penyalahgunaan narkotika yang dilakukan oleh anak-anak pada dasarnya adalah dilema. Kemampuan hukum pidana sebagai alat untuk mengatasi penyalahgunaan narkotika oleh anak terbatas. Hal ini dapat dilihat dari naiknya penyalahgunaan narkotika oleh anak, di sisi lain adnaya kecenderungan hukum pidana digunakan sebagai alat mengatasi penyalahgunaan narkotika oleh anak (Adi, 2009).

Contoh kasus anak yang melalui diversi yaitu pada hari Rabu tanggal 26 Agustus 2015 sekitar pukul 18.30 wita, diperoleh informasi bahwa terdakwa anak yang berada di tempat kos kakaknya di daerah Denpasar dan melakukan penggeledahan oleh Ketut Gatra Adnyana dan saksi I Wayan Budiana melakukan penggeledahan pada badan dan baju terdakwa anak yang menemukan 2 (dua) plastic klip yang berisi Kristal itu sabu-sabu dengan berat bersih 4,17 gram dan 4,83 gram, 1 (satu) plastik berisi 10 (sepuluh) butir tablet Narkotika jenis ekstasi dengan berat bersih 3,01 dan di karton plastic merk Little $M$ di temukan plastik besar yang berisi Kristal bening narkotika jenis sabu-sabu dengan berat bersih sebanyak 83,00 gram. Atas masuknya informasi penggeledahan terdakwa anak di Polresta Denpasar maka perkara ini dilanjutkan di tahap penyelidikan dan sidang dengan diupayakannya kejalur banding yang akhirnya hakim memutuskan untuk menjatuhkan pidana terhadap terdakwa anak dengan pidana penjara 3 (tiga) tahun di Lembaga Pembinaan Khusus Anak di Karangasem dan pidana Pelatihan kerja selama 4 (empat) bulan di Yayasan Genersi Bisa Indonesia di Banjar Gempinis desa Dalang kecamatan Selemadeg Timur kabupaten Tabanan. Hal ini dilakukan supaya anak dapat dibina lebih baik lagi dengan dijatuhkannya pidana di lembaga pembinaan, kemudian nantinya anak tersebut mendapatkan ilmu keterampilan yang baru dan juga tetap bisa menjalankan kehidupanya kembali dengan normal dan lebih baik lagi serta bisa kembali ke lingkungan sosial dengan baik, tanpa menggangu mental dan pisikis terdakwa anak. 
Berdsarakan uraian di atas, maka penelitian ini bertujuan untuk mengetahui dasar pertimbangan hakim dalam menjatuhkan sanksi pidana terhadap anak sebagai perantara narkotika, dan untuk mengetahui perlindungan hukum terhadap anak sebagai perantara narkotika.

\section{METODE PENELITIAN}

Metode penelitian yang digunakan dalam penelitian ini adalah metode penelitian hukum normatif yaitu dengan mengkaji peraturan perundang-undangan yang berlaku (Soekanto \& Mamudji, 2006). Sumber bahan hukum dalam penelitian ini adalah sumber bahan hukum primer dan sekunder. Teknik pengumpulan bahan hukum menggunakan teknik studi pencatatan dan studi dokumentasi. Bahan hukum yang sudah terkumpul kemudian dianalisis dengan menggunakan argumentasi hukum yang didasarkan atas logika hukum deduktif.

\section{HASIL PENELITIAN DAN PEMBAHASAN}

\section{Pertimbangan Hakim dalam Menjatuhkan Sanksi Pidana terhadap Anak sebagai Perantara Narkotika}

Hakim ketua dalam menjatuhkan sanksi pidana akan selalu dipertimbangkan oleh hakim yang lain atau hakim anggota, terutama dalam kasus di mana anak-anak adalah perantara narkotika. Dalam ketentuan Undang-undang disebutkan bahwa hakim adalah pejabat pengadilan negara yang diberi wewenang oleh hukum untuk mengadili. Hakim diberikan wewenang oleh hukum melaksanakan dan mengadili kasus yang diserahkan ke pengadilan. Adapun tugas-tugas seorang hakim antara lain:

1. Menerima setiap kasus yang datang kepadanya;

2. Periksa setiap kasus yang diserahkan kepadanya;

3. Mengadili dan menyelesaikan kasus yang diajukan kepadanya.

Hakim berdomisili karena penyelesaian setiap konflik yang muncul selama konflik diatur dalam undang-undang. Melalui hakim, kehidupan manusia dalam suatu masyarakat harus dibangun berdasarkan nilai-nilai kemanusiaan. Karena itu, dalam menjalankan pekerjaannya, tidak diperbolehkan memihak selain kepada kebenaran dan nilai keadilan serta nilai kemanusiaan. Pertimbangan hakim adalah aspek penting dalam mewujudkan nilai putusan hakim yang adil (ex aequo et bono) dan terkandung unsur kepastian hukum, selain itu terkandung manfaat bagi para pihak sesuai dengan kepentingan mereka masing-masing. Putusan hakim berdasarkan pertimbangan hakim dapat dibatalkan oleh pengadilan tinggi apabila terdapat pertimbangan yang tidak teliti, baik dan cermat (Arto, 2004). Hakim dalam memeriksa suatu kasus juga membutuhkan bukti, di mana hasil bukti akan digunakan sebagai pertimbangan dalam memutuskan kasus tersebut. Bukti adalah tahap terpenting dalam memeriksa kasus di persidangan. Pembuktian dilakukan dengan tujuan mendapatkan kepastian bahwa peristiwa yang disampaikan itu memang benar terjadi sehingga hakim dapat membuat keputusan yang adil dan benar. Sebelum terbukti adanya peristiwa/ fakta yang benar terjadi dan terbukti kebenarnanya, dan nampak ada hubungan hukum antara para pihak, hakim tidak boleh membuat keputusan (Arto, 2004).

Dasar pertimbangan hakim membuat keputusan pengadilan harus berdasarkan pada teori dan hasil penelitian yang saling terkait dengan keputusan hasil persidangan yang menggunakan hal-hal yang memberatkan dan memitigasi sehingga hasil penelitian dimaksimalkan dan seimbang di tingkat teori dan praktik. Adapun upaya terjadinya kepastian hukum di peradilan, maka hakim merupakan penegak hukum dengan keputusan yang dibuat oleh mereka. Keputusan itu dijadikan tolak ukur untuk mencapai kepastian hukum. Pokok kekuasaan kehakiman diatur dalam peraturan perundangan yang berlaku. Anak-anak sebagai perantara narkotika dan telah ditetapkan sebagai terdakwa, anakanak telah melanggar perundangan yang berlaku yang ancaman kriminalnya sehingga diancam hukum penjara selama lima tahun dan bisa mencapai dua puluh tahun. Tindakan anak sebagai terdakwa tidak mendukung program yang dilakukan oleh pemerintah untuk melawan kejahatan narkotika. Mengingat tedakwa masih di bahwa umur, maka dia perlu dilindungi hak-haknya, secara psikologis, harus dilakukan konseling sehingga dia tidak melakukan tindakannya lagi, dan juga terdakwa memperlihatkan kesopanan selama dilakukan sidang. Dan juga anak tidak pernah dihukum dan mau mengakui bahwa dia menyesal melakukan tindakan tersebut.

Putusan Nomor: 14Pid.Sus.Anak/2015/PN.Dps, terdakwa anak dinyatakan secara sah dan meyakinkan bersalah atas kejahatan Narkotika karena tanpa hak untuk menyimpan, menguasai dan menyediakan Kelompok Narkotika I bukan tanaman yang beratnya lebih dari 5 (lima) gram. Tidak sesuai dengan perundang-undangan dan memberikan hukuman pidana penjara 3 tahun di Yayasan 
Pembina kasus Anak dan melakukan pelatihan kerja selama empat bulan di yayasan generasi Biasa Tabanan Bali. Hukuman kurungan yang diberikan pada tergugat anak dilakukan untuk penegakan hukum di masyarakat karena terdakwa melakukan pelanggaran perundangan tentang narkotika dalam tindakan memiliki, menyimpan, mengendalikan, dan menyediakan kelompok narktoka I bukan sebagai tanaman seperti dimaksud dalam perundangan yang beratnya lebih dari lima gram dan memberikan hukuman kurungan selama lima tahun dan bisa mencapai 20 tahun dan hukuman maksimal seperti dalam peraturan perundangan yang unsur-unsurnya dapat dibuktikan di pengadilan dan tindakan terdakwa dianggap tidak mendukung program pemerintah untuk melawan sirkulasi narkotika. Hukuman kurungan diberikan pada tergugat anak karena tergugat anak dikatakan dapat memikul tanggung jawab atas reparasi jika terlihat usia tergugat anak pada saat ditangkap adalah tujuh belas tahun.

\section{Perlindungan Hukum terhadap Anak sebagai Perantara Narkotika}

Perlindungan hukum adalah penyempitan makan perlindungan, sifatnya hanya perlindungan hukum. Perlindungan yang dilakukan hukum, berkaitan dengan hak dan kewajiban, yang dimiliki manusia sebagai subjek hukum dalam hubungannya sebagai manusia dan dengan lingkungannya. Sebagai subjek hukum, manusia mempunyai hak dan kewajiban untuk mengambil tindakan hukum (Marlina, 2009). Perlindungan hukum diberikan untuk melindungi hak asasi manusia yang dirugikan dan melindungi masyarakat sehingga dapat menikmati hak yang diberikan oleh hukum. Dengan demikian perlindungan hukum $b$ merupakan langkah hukum yang diberikan oleh petugas penegak hukum dalam memberikan keamanan, sehingga terbebas dari berbagai gangguan dan ancaman dari pihak manapun (Hidayat, 2010). Perlindungan hukum untuk anak-anak diharapkan dapat memberikan perlindungan terhadap hak-hak mereka sehingga terhindar dari penanganan yang salah di dalam proses peradilan pidana. Ketentuan hukum tentang anak diatur dalam peraturan perundangan, dimana pelaksanaan hukuman sangat efektif dalam melakukan pembinaan dan perlindungan kepada anak (Shulton, 2015).

Diversion adalah salah satu langkah melindungi anak yang memiliki masalah dengan hukum sebagai perwujudan keadilan restoratif dalam memberikan perlindungan hak-hak anak. Pengurangan hukuman kurungan oleh Pengadilan Negeri Denpasar adalah untuk memberikan perlindungan hukum bagi anak sebagai terdakwa, sedangkan Tergugat Anak adalah anak di bawah umur yang secara psikologis masih labil dan perlu pembinaan dan konseling sehingga tidak melakukan perbuatan itu lagi, dan perlu dihukum untuk memberikan perlindungan terhadap hak-hak mereka. Dan hukuman penjara yang dijatuhkan bukan hanya hukuman pidana, tetapi agar anak merasa jera sehingga kedepannya tidak melakukan perbuatan itu lagi. Kasus Pengadilan Negeri Denpasar juga menjatuhkan sanksi 4 (empat) bulan pelatihan di Yayasan Generasi Biasa Indonesia kepada Tergugat. Yayasan memberikan pelatihan kepada anak agar anak belajar mandiri sehingga nanti apabila sudah keluar dari penjara anak bisa kembali ke masyarakat dan memiliki keterampilan yang tidak tergoda lagi untuk bekerja sebagai perantara narkotika. Kitab Undang-Undang Hukum Pidana Anak menentukan bahwa sistem Prosedur Acara Pidana dijalankan berdasarkan prinsip-prinsip perlindungan, keadilan, non-diskriminasi, kepentingan terbaik anak, menghormati pendapat anakanak, tumbuh kembang hidup anak dan perkembangan anak, bimbingan dan bimbingan untuk anakanak, secara normal, perampasan kebebasan dan hukuman merupakan langkah akhir untuk menghindari pembalasan.

\section{SIMPULAN \& SARAN}

\section{Simpulan}

Berdasarkan uraian hasil penelitian di atas, dapat disimpulkan bahwa dasar pertimbangan hakim dalam menjatuhkan sanksi pidana terhadap anak-anak sebagai perantara narkotika dalam Keputusan Nomor 14/Pid.Sus Anak/2015/PN.Dps adalah Undang-Undang Nomor 35 Tahun 2009 tentang Narkotika, menjelaskan secara umum tentang sanksi pidana untuk perantara (kurir) narkotika namun tidak secara khusus mengatur pemberian hukuman untuk anak-anak sebagai perantara. Tetapi pada dasarnya para penyelundup narkotika tentang anak-anak sebagai perantara narkotika masih dituntut sesuai dengan peraturan perundangan yang berlaku. Perlindungan hukum bagi anak-anak yang melakukan pelanggaran terhadap kasus pidana dapat memberikan perlindungan kepada hak anak. Keadilan Restoratif sebagai tujuan dalam menerapkan Sistem Peradilan Pidana Anak dimaksudkan 
untuk dapat menjauhkan anak-anak dari proses peradilan sehingga mereka dapat menghindari stigma terhadap anak-anak yang dihadapkan dengan hukum dan anak dapat kembali ke lingkungan sosial secara adil dan benar. Karena kejahatan Narkotika adalah kejahatan tanpa korban, anak-anak yang terlibat dalam kejahatan narkotika harus dianggap sebagai korban

\section{Saran}

Adapun saran yang hendak disampaikan ke berbagai pihak terkait yakni: kepada petugas penegak hukum, penjara pidana bukanlah cara yang efektif untuk menyelesaikan kasus pada anak-anak. Anak yang memiliki masalah dan dihukum dengan hukuman penjara berdampak tidak bagi pagi psikologis anak dan memberikan pengaruh buruk lainnya. Kemudian, kepada orang tua anak menurut pendapat saya, lebih baik menjaga lingkup hubungan anak dan harus berkomunikasi lebih banyak dengan anak sehingga anak tidak jatuh ke dalam pelanggaran pidana dan orang tua harus selalu tahu kegiatan apa yang sedang dilakukan. oleh anak, mengingat meningkatnya prevalensi anak yang menjadi korban pergaulan bebas seperti penyalahgunaan narkotika.

\section{DAFTAR PUSTAKA}

Adi, K. (2009). Kebijakan Kriminal dalam PenanggulanganTindak Pidana Narkotika Oleh Anak. Malang: UMM Press.

Arto, M. (2004). Praktek Perkara Perdata pada Pengadilan Agama (Cet. V). Yogyakarta: Pustaka Pelajar. Gultom, M. (2014). Perlindungan Hukum terhadap Anak. (A. Gunarsa, Ed.). Bandung: Refika Aditama. Hidayat, B. (2010). Pemidanaan Anak di Bawah Umur. Bandung: Alumni.

Marlina. (2009). Peradilan Pidana Anak di Indonesia : Pengembangan Konsep Diversi dan Restorative Justice. (N. F. Atif, Ed.). Bandung: PT. Refika Aditama.

Prajnaparamita, K. (2018). Perlindungan Tenaga Kerja Anak. Administrative Law and Governance Journal, 1(1), 112-128.

Shulton, H. A. (2015). Status Hukum dan HAM dalam Sistem Peradilan Pidana Anak di Indonesia. Jakarta.

Soekanto, S., \& Mamudji, S. (2006). Penelitian Hukum Normatif Tinjauan Singkat. Jakarta: Rajawali Pers.

Sujono, A., \& Daniel, B. (2011). Komentar dan Pembahasan: Undang-Undang Nomor 35 Tahun 2009 tentang Narkotika. Jakarta: Sinar Grafika. 